\title{
Purwarupa Sistem Prediksi Luas dan Hasil Panen Padi suatu Wilayah menggunakan Pengolahan Citra Digital dengan Metode Sobel dan Otsu
}

\author{
Ardya Yunita Putri*1, Raden Sumiharto ${ }^{2}$ \\ ${ }^{1}$ Prodi Elektronika dan Instrumentasi, Jurusan Ilmu Komputer dan Elektronika, FMIPA UGM \\ ${ }^{2}$ Jurusan Ilmu Komputer dan Elektronika, FMIPA UGM, Yogyakarta \\ e-mail: *
}

\begin{abstract}
Abstrak
Sistem prediksi luas dan hasil panen padi suatu wilayah menggunakan pengolahan citra dengan metode Sobel Otsu ini merupakan salah satu sistem yang memanfaatkan data foto udara untuk prediksi luas dan hasil panen. Metode Otsu digunakan pada proses thresholding dan metode Sobel digunakan untuk mendeteksi tepi wilayah sawah. Kemudian dilakukan proses filtering agar pada proses scanning piksel putih yang dihitung jumlahnya hanya yang ada pada wilayah yang diinginkan. Setelah didapatkan jumlah piksel putih kemudian jumlah tersebut dikalikan dengan nilai yang didapatkan dari proses kalibrasi serta dengan perkiraan hasil panen padi $\left(\mathrm{kg} / \mathrm{m}^{2}\right)$.

Pendeteksian warna kuning padi siap panen dilakukan dengan pengolahan warna dari citra HSV kemudian dideteksi menggunakan thresholding HSV. Pada pengujian variasi warna padi, warna padi yang terdeteksi merupakan warna padi siap panen yaitu bewarna kuning kecoklatan yang kemudian didapatkan warna yang terdeteksi dengan warna putih kemudian digunakan untuk proses prediksi luas dan hasil panen. Kemudian pengujian akurasi perhitungan didapatkan tingkat error yang berbeda pada wilayah sawah yang berbeda. Error pada pengujian sistem ini yaitu 3,1 \%, 8,7\%, 4,9\% dan 248\%. Pada error tertinggi diakibatkan pencahayaan yang berlebih sehingga warna hijau padi terdeteksi menjadi oleh sistem bewarna kuning serta dikarenakan terdapat wilayah yang tertutupi oleh pohon sehingga mengurangi perhitungan luas sawah.
\end{abstract}

Kata kunci-foto udara, deteksi warna, thresholding, deteksi tepi, perhitungan luas.

\section{Abstract}

Area and paddy crop yield prediction system of an area using image processing by Sobel Otsu's method is one of system that utilize aerial photo data for measuring area and prediction of its crop yield. Otsu's method is used to thresholding process and Sobel's method is used to detect paddy field's edges that will calculate its area. Then filtering process so that the scanning process white pixels are counted only exist in the desired region. After the amount of white pixel(s) is obtained, their amount is multiplied with the scale that obtained from calibration process and crop yield prediction $(\mathrm{kg} / \mathrm{m} 2)$.

Detection of yellow paddy color that ready-to-harvest is successfully performed by processing the HSV color, which is then detected by thresholding HSV. At the time of testing with variety of paddy color, the detected paddy color is the paddy color ready-to-harvest, which is brownish yellow that represented by white pixels, and will be used then to predict its area and crop yield. Thereafter, accuracy calculation test resulting in different error levels in different paddy fields. Error in testing of this system are 3,1\%, 8,7\%, 4,9\% dan 248\%. The highest error value is caused by excessive exposure of light, with the result that the green color on paddy is detected by the system as yellow and some areas are covered by trees that, thereby reducing paddy fields area calculation.

Keywords-aerial photographs, color detection, thresholding, edge detection, area calculation. 


\section{PENDAHULUAN}

$\mathrm{F}$ otografi merupakan suatu kegiatan yang hampir dilakukan oleh semua orang. Kegiatan fotografi ini dilakukan baik dengan kamera untuk professional maupun menggunakan kamera pada handphone untuk fotograder amatir. Jenis kamera yang digunakan dalam kegiatan ini pun beragam sesuai dengan kebutuhan masing-masing dalam pengambilan gambar. Fotografi di masa sekarang telah digunakan diberbagai bidang seperti bidang militer, sipil, pertanian dan lain-lain. Pada penggunaan dibidang militer fotografi telah berkembang pesat. Pemasangan kamera pada pesawat tanpa awak menjadi solusi untuk kegiatan pengintaian dan pemngambilan gambar untuk wilayah yang sulit dijangkau. Kemudian untuk keperluan dibidang sipil, foto udara dengan pesawat tanpa awak dapat digunakan untuk pemantauan hutan, pemetaan daerah serta untuk pemantauan terjadinya bencana alam untuk pencarian korban. Bahkan untuk saat ini foto udara dapat menjadi peluang bisnis untuk jasa foto iklan ataupun pengambilan gambar pada saat penerimaan mahasiswa baru.

Indonesia merupakan negara yang memiliki karakteristik wilayah serta bentang lahan bervariasi. Dengan menggunakan pesawat tanpa awak dapat membantu pengambilan gambar dari penampakan alam melalui foto udara. Dengan menggunakan pesawat tanpa awak ini terdapat keuntungan yaitu dapat mempersingkat waktu pemantauan suatu daerah. Dapat pula pengambilan foto udara melalui foto satelit, tetapi foto satelit biasanya tidak realtime sehingga keadaan yang akan dipantau merupakan hasil pemotretan dari beberapa hari atau beberapa bulan yang lalu.

UAV (Unmanned Aerial Vehicle) merupakan sebuah pesawat tanpa awak yang dikendalikan dari jarak jauh atau diterbangkan secara mandiri yang dilakukan pemrograman terlebih dahulu atau secara otomatis. Pemotretan yang wilayah dengan UAV ini dapat dikendalikan dari jarak jauh. Untuk mempermudah kegiatan fotografi ini sebagai pemetaan dengan pesawat tanpa awak membawa perangkat keras kamera untuk mengambil gambar.

Hasil gambar yang didapat dari kamera yang berupa citra masih belum cukup untuk mencakup wilayah yang akan dijadikan objek foto udara. Untuk mendapatkan hasil gambar yang lebih luas digunakan pengolahan citra stitching atau penggabungan citra. Setelah dilakukan penggabungan citra masih terdapat informasi yang dapat ditambahkan seperti luas wilayah yang difoto. Seperti informasi luas area persawahan. Karena Indonesia merupakan negara yang agraris sehingga dibutuhkan informasi luas area persawahan yang ditanami padi dan dari informasi luas tersebut dapat digunakan untuk memprediksi hasil panen tanaman padi sehingga salah satu solusi yang dapat digunakan adalah dengan menggunakan sawah yang terdapat padi siap panen sebagai objek foto udara. Foto udara digunakan sebagai salah satu cara mengukur luas sawah yang ditanami padi karena dapat menghemat waktu pengukuran, lebih mudah dan data yang didapat lebih akurat.

\section{METODE PENELITIAN}

\subsection{Tinjauan Pustaka}

Foto udara atau photomapping merupakan pengambilan gambar yang berbasis representasi metrik untuk mendapatkan gambaran dari linkungan melalui pemotretan lewat udara. Untuk sudut pandang yang sederhana, wilayah tumpang tindih antara dua gambar berurutan mengakuisisi harus ditemukan dan sesuai kecocokan dari photomapping yang terkait dengan ordometry visual yang juga memungkinkan memperkirakan suatu pergerakan [1].

Foto udara dengan pengolahan citra telah banyak dilakukan terutama untuk mengidentifikasi perubahan bentuk, luas ataupun kondisi lainnya dari suatu wilayah. Melalui berbagai tahapan pengolahan, dapat diperoleh informasi yang diinginkan tentang fitur tertentu dari sebuah citra digital antara lain luas atau ukuran objek. Salah satunya adalah penelitian dari pemanfaatan citra penginderaan jauh dan sistem informasi geografis untuk pemetaan lahan 
kritis. Yang dilakukan oleh [2]. Dalam penelitian ini tujuannya adalah mengetahui kemampuan citra penginderaan jauh ALOS AVNIR-2 untuk identifikasi penggunaan lahan sebagai parameter pengaruh lahan kritis dan mengetahui luas lahan kritis di Kabupaten Banjarnegara akibat pengaruh penggunaan lahan menggunakan pendekatan bilangan kurva.

Pemanfaatan yang lain adalah pemanfaatan citra dari satelit yang digunakan untuk menghitung luas daerah bekas penambangan timah. Dalam penelitian ini, dilakukan pengolahan citra digital dari suatu wilayah tertentu di Provinsi Kepulauan Bangka Belitung yang memiliki daerah bekas penambangan timah untuk dapat diketahui luasnya. Penelitian dimulai dengan survei lapangan untuk memperoleh data berupa koordinat serta ukuran (panjang dan lebar) daerah bekas penambangan timah. Koordinat tersebut digunakan untuk memperoleh citra satelit dari daerah bekas penambangan timah. Selanjutnya, citra satelit berupa citra warna (RGB) diubah menjadi citra grayscale. Citra grayscale kemudian diperbaiki melalui proses perenggangan kontras, lalu diubah menjadi citra biner. Operasi morfologi yaitu erosi dan dilasi diterapkan pada citra biner tersebut sehingga dapat dihitung jumlah piksel objek (daerah bekas penambangan timah) di dalam citra. Ukuran sebenarnya (panjang dan lebar) daerah bekas penambangan timah digunakan untuk mengetahui nilai skala yang diperlukan guna menghitung luas objek citra (daerah bekas penambangan timah) dalam satuan $\mathrm{m}^{2}$ [3].

Penggunaan foto udara untuk pengambilan citra dengan menggunakan citra yang didapat dengan UAV lebih unggul daripada menggunakan citra satelit. Kelemahan dari penggunaan citra satelit adalah ketinggian dari awan dapat menyebabkan tidak jelasnya area secara keseluruhan, terutama di daerah equator dimana sangat berawan. Kemudian dengan citra satelit warna yang diberikan rendah karena bayangan dari awan membuat kedekatan area gelap dengan sedikit perbandingan atau kontras. Tetapi dengan menggunakan UAV, masalah bayangan sangat rendah dengan pengenalan warna yang tinggi pada foto dengan dinamik yang baik [4].

Data penginderaan jauh (inderaja) telah banyak digunakan untuk identifikasi dan pemantauan kondisi penggunaan lahan pertanian. Penggunaan citra satelit optik seringkali terkendala oleh tutupan awan, ketergantungan pada penyedia data, harga yang relatif mahal, dan waktu akuisisi dan lokasi data yang diperlukan tidak fleksibel. Teknologi pesawat terbang tanpa awak (UAV) telah dikembangkan dan banyak digunakan untuk aplikasi penginderaan jauh untuk pertanian. Pesawat tanpa awak (Unmanned Air Vehicle - UAV) yang dilengkapi sensor yang hampir mirip dengan sensor pada satelit memungkinkan memberikan hasil yang dapat digunakan untuk menganalisis kondisi tanaman / vegetasi atau lahan pertanian dengan menggunakan band VNIR, SWIR, thermal, radar atau SAR. Teknologi UAV dapat diterbangkan kapan saja, untuk merekam data penggunaan lahan pertanian pada saat diperlukan. Penerapannya di Indonesia terkendala oleh biaya awal yang tinggi, keterbatasan teknologi yang tersedia, dan kemampuan sumberdaya manusia terhadap teknologi tersebut masih terbatas. Terlepas dari kendala tesebut, penggunaan teknologi UAV mempunyai prospek yang baik untuk digunakan secara operasional di sektor pertanian. Penelitian dan pengembangan terhadap aplikasi UAV untuk bidang pertanian perlu terus dilakukan[5].

Penelitian [6] melakukan penelitian tentang foto panorama. Foto panorama adalah teknik merekam sebuah image yang lebarnya melebihi pandangan lurus mata normal, jika diukur menggunakan focal length pandangan normal, lebih kurang $50 \mathrm{~mm}$ (lensa normal) dengan kelebaran 46 derajat. Oleh karena itu, diadakanya suatu teknik penggabungan agar mendapat sebuah foto panorama.

\subsection{Analisa Kebutuhan Sistem}

Fotografi di masa sekarang telah digunakan di berbagai bidang seperti bidang militer, sipil, pertanian dan lain-lain. Pemasangan kamera pada pesawat tanpa awak menjadi solusi untuk mempermudah kegiatan fotografi pemantauan udara. Dari data hasil pemotretan wilayah menggunakan UAV ini dapat dimanfaatkan untuk perhitungan luas suatu wilayah. Karena Indonesia merupakan negara yang agraris sehingga dibutuhkan informasi luas area persawahan

Purwarupa Sistem Prediksi Luas dan Hasil Panen Padi suatu Wilayah ...(Ardya Yunita Putri) 
yang ditanami padi dan dari informasi luas tersebut dapat digunakan untuk memprediksi hasil panen tanaman padi sehingga salah satu solusi yang dapat digunakan adalah dengan menggunakan sawah yang terdapat padi siap panen sebagai objek foto udara.

Pada penelitian ini dibuat sebuah sistem yang digunakan untuk prediksi luas dan hasil panen dengan pengolahan citra. Sistem pengukuran luas sawah dan prediksi hasil panen padi pada suatu wilayah ini memanfaatkan hasil dari pemotretan udara sawah dengan menggunakan UAV. Hasil foto udara sawah dengan padi yang menguning yang telah tersedia ini kemudian dimanfaatkan dengan pembuatan sistem pengukur luas sawah dan prediksi hasil panen padinya dengan menggunakan pengolahan citra. Sebelum pembuatan sistem kemudian dilakukan analisis dari perancangan sistem tersebut. Analisis kebutuhan sistem menjelaskan hal-hal yang dibutuhkan dalam perancangan sistem. Hasil analisis kebutuhan sistem berupa metode pengumpulan data, masukan sistem, keluaran sistem, kebutuhan perangkat keras dan perangkat lunak yang digunakan.

\subsection{Deskripsi Sistem}

Pada penelitian ini dibuat sebuah sistem yang digunakan untuk memprediksi luas sawah dan hasil panen padi pada suatu wilayah dengan pengolahan citra. Pada sistem prediksi luas dan hasil panen padi ini menggunakan pengolahan citra maka dibutuhkan perangkat lunak yang dapat mempermudah dalam pemrosesan pengolahan citra. Pada sistem ini digunakan pustaka OpenCV. Pustaka OpenCV ini digunakan pada proses pendeteksian warna padi yang siap panen, metode Otsu untuk proses thresholding, proses filtering dan metode Sobel untuk pendeteksian tepi objek. Proses pertama adalah pendeteksian warna citra padi yang siap panen. Pada pendeteksian warna ini pengolahan warna citra yang digunakan adalah pengolahan warna HSV. Citra yang digunakan sebagai masukan masih memiliki format warna RGB yang kemudian diubah kedalam format citra HSV. Pengolahan warna HSV ini digunakan untuk mempermudah pendeteksian warna kuning padi yang siap panen yaitu warna kuning kecoklatan. Penggunaan warna HSV ini dikarenakan format ini sangat baik untuk membedakan warnawarna yang 'terlihat'. HSV (hue, saturation, value) merupakan model warna yang diturunkan dari RGB serta performa HSV ternyata lebih baik dalam membedakan warna jika dibandingkan dengan RGB [7].

Kemudian thresholding untuk membedakan antara 2 bagian yaitu latar depan (foreground) dan latar belakang (background) pada citra. Metode yang digunakan untuk thresholding ini adalah metode Otsu. Metode Otsu ini digunakan untuk memaksimalkan hasil perhitungan dari proses threshholding. Metode ini digunakan untuk menentukan nilai ambang atau T. Dengan metode ini nilai ambang T dapat terhitung otomatis berdasarkan citra masukan. [8].

Dari hasil thresholding ini kemudian dilakukan filtering yang berguna untuk menghilangkan bercak-bercak putih yang bukan merupakan begian dari objek yang akan dihitung luasnya. Filter yang digunakan pada sistem ini adalah Median filtering. Median filtering memberikan hasil yang lebih baik untuk citra yang mengalami gangguan dalam bentuk spike berupa bercak-bercak putih maupun dalam bentuk salt and pepper. [9].

Kemudian metode Sobel digunakan untuk mendeteksi tepi objek citra yang akan dihitung luasnya sebelum dilakukan scanning area citra yang digunakan untuk perhitungan piksel putih yaitu piksel objek. Metode Sobel mempunyai kelebihan dari metode ini adalah kemampuan untuk mengurangi noise sebelum melakukan perhitungan deteksi tepi.[10].

Kemudian hasil dari perhitungan piksel dari proses scanning digunakan untuk perhitungan prediksi luas dan hasil panen padi pada suatu area sawah siap panen.Dari hasil sistem yang dirancang terdapat beberapa keluaran hasil dari sistem perhitungan luas dan prediksi hasil padi siap panen. Keluaran sistem berupa hasil dari pengolahan citra serta hasil dari perhitungan luas dan prediksi hasil panen padi. Setiap hasil proses pengolahan citra akan ditampilkan seperti hasil dari deteksi warna, thresholding, dan hasil deteksi tepinya. Hasil perhitungan luas dan prediksi hasil panen padi ditampilkan pada terminal. 


\subsection{Implementasi}

Implementasi dari sistem prediksi luas dan hasil panen padi suatu wilayah menggunakan pustaka OpenCV 2.4.9 pada Linux Ubuntu 12.04 LTS 64 bit. Data yang digunakan dalam penelitian ini dalah data citra sawah pada suatu wilayah dengan padi yang bewarna kuning yang kemudian melakukan proses pengolahan citra digital. Proses ini akan mendeteksi sawah dengan warna padi yang menguning kemudian langkah selanjutnya thresholding dan filtering yang kemudian citra hasil akan dihitung jumalah piksel puithnya yang akan digunakan untuk perhitungan prediksi luas dan hasil panen. Luaran dari sistem ini akan menampilkan hasil perhitungan luas dan hasil panen beserta gambar hasil proses pengolahan citra. Bagan alir dari proses implementasi sistem prediksi luas dan hasil panen padi ditunjukkan pada Gambar 1.

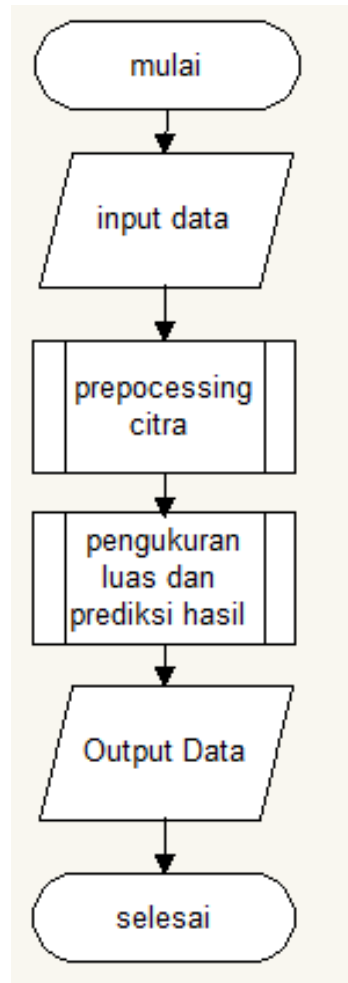

Gambar 1 Bagan alir sistem prediksi luas dan hasil panen padi

Implementasi program utama pada sistem ini terdiri dari dua tahap yaitu preprocessing citra dan proses perhitungan prediksi luas dan hasil panen. Sebelum tahap pertama yaitu preprocessing citra, terlebih dahulu memasukkan pustaka-pustaka dari OpenCV yang akan digunakan pada pemrograman sistem ini. Salah satu tahap dari implementasi perangkat lunak ini adalah tahap preprocessing citra. Data citra yang disimpan kemudian pada notebook yang digunakan untuk mengolah data yang kemudian dimasukkan pada program sesuai nama dari data tersebut. Data yang dimasukkan pada program kemudian dibaca dan kemudian diproses pada tahap selanjutnya. Proses selanjutnya adalah pendeteksian warna. Warna yang akan dideteksi adalah warna padi yang siap panen sehingga warnanya kuning kecoklatan. Pada pengolahan citra, setiap warna yang akan dideteksi mempunyai range warna yang berbedabeda.Tahap selanjutnya adalah proses pengukuran luas dan prediksi hasil panen. Pada proses ini, jumlah piksel citra yang bewarna putih akan dihitung kemudian untuk perhitungan luasnya dikalikan dengan sklala gambar yang didapat dari proses kalibrasi. 


\section{HASIL DAN PEMBAHASAN}

\subsection{Pengujian variasi warna padi}

Pada pengujian warna, penentuan rentang warna HSV dengan program manual yang kemudian diguanakan pada program pengukuran luas. Nilai rentang HSV yang dicari adalah rentang nilai HSV warna kuning pada padi yang siap panen yang warnanya kuning kecoklatan. Nilai rentang HSV yang digunakan adalah pada rentang minimal 16,6 untuk nilai $\mathrm{H}, 106,4$ untuk nilai S, dan 70 untuk V serta pada rentang maksimal 29,6 untuk nilai $\mathrm{H}, 227,8$ untuk nilai S, dan 183 untuk nilai V. Sehingga pada pengujian warna ini diujikan dengan masukan gambar dengan variasi warna padi yang masih hijau, hampir menguning, menguning, dan menguning kecoklatan. Kemudian pada citra padi yang menguning kecoklatan atau siap panen pun juga mempunyai rentang warna yang berbeda-beda. Hal ini dikarenakan jumlah intensitas cahaya yang berbeda-beda pada setiap tempat. Perbandingan hasil dari variasi warna padi ditunjjukkan pada Tabel 1.

Tabel 1 Perbandingan hasil dari variasi warna padi

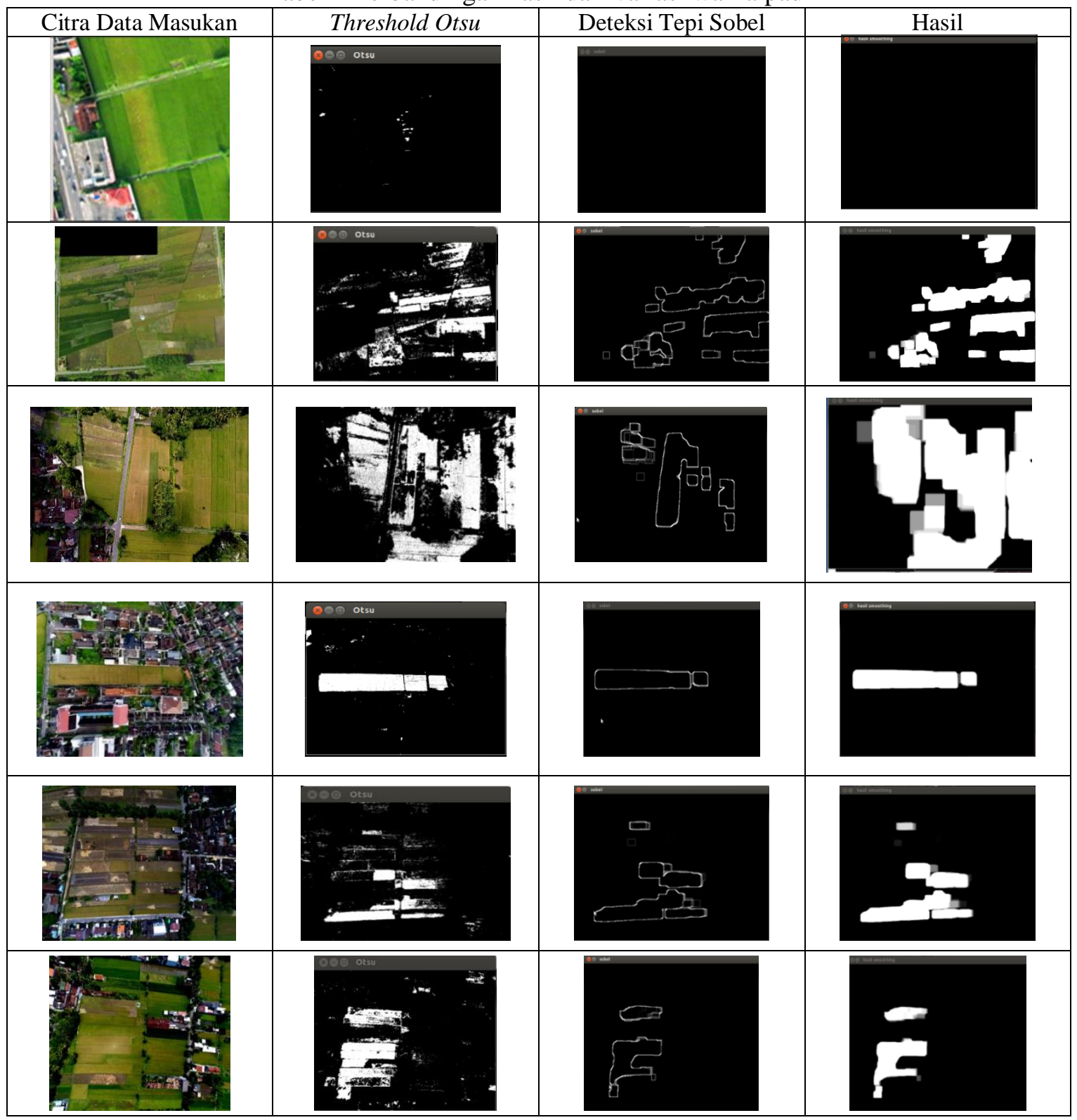

IJEIS Vol. 6, No. 2, October 2016 : $187-198$ 
Dari data diatas dapat dilihat bahwa pada sistem ini yang dapat dideteksi adalah warna padi yang menguning atau padi yang akan dipanen. Sehingga sawah yang dapat dihitung luasnya yaitu sawah dengan tanaman padi yang menguning atau akan panen. Citra yang dimasukkan yang kemudian akan di deteksi warnanya akan di threshold yang kemudian citra akan dibedakan menjadi hitam dan putih yaitu bagian background dan foreground untuk membedakan bagian yang dideteksi sebagai warna kuning padi dengan yang bukan wilayah yang terdeteksi sebagai warna padi. Pada proses pengolahan citra ini dapat dilihat masih terdapat noise yang terdeteksi, hal ini dikarenakan warna kuning merupakan warna yang hampir mendekati warna putih dan pada saat pengambilan data terdapat pantulan dari sinar matahari sehingga dapat menganggu dalam proses pengolahan citra. Metode yang digunakan adalah metode Otsu dan metode Sobel.

Metode Otsu pada sistem digunakan untuk memaksimalkan nilai ambang atau thresholding. Pada penelitian-penelitian yang pernah dilakukan dengan metode Otsu, metode ini digunakan untuk proses dari proses RGB ke proses grayscale kemudian proses binersiasi, tetapi pada sistem ini proses yang dilakukan dengan deteksi warna HSV kemudian dilakukan proses threshold HSV pada tahap pendeteksian warna dan kemudian melakukan proses thresholding kembali dengan metode Otsu. Pada sistem ini penggunaan metode Otsu memanfaatkan pustaka yang terdapat pada pustaka OpenCV. Tabel 2 merupakan gambar dari perbedaan setelah dilakukan thresholding HSV kemudian setelah dilakukan thresholding Otsu.

Metode Sobel yang digunakan untuk membatasi tepi wilayah yang akan diproses dan dihitung luasnya. Metode ini akan mengurangi noise sebelum melakukan deteksi tepi. Pada prosesnya metode ini akan mendeteksi tepi dengan memperhatikan tepi vertical (gradient $\mathrm{Y}$ ) dan horizontal (gradient X) objek. Bila edge yang ditemukan merupakan sekumpulan piksel signifikan yang membentuk objek image, maka warna piksel tersebut akan di pertegas kembali, artinya piksel ini akan di perbesar intensitasnya sehingga warna edge ini akan tampak jelas. Keadaan edge yang demikian nantinya akan memperlihatkan suatu objek dalam image.

Tabel 2 Perbandingan threshold HSV dan threshold Otsu

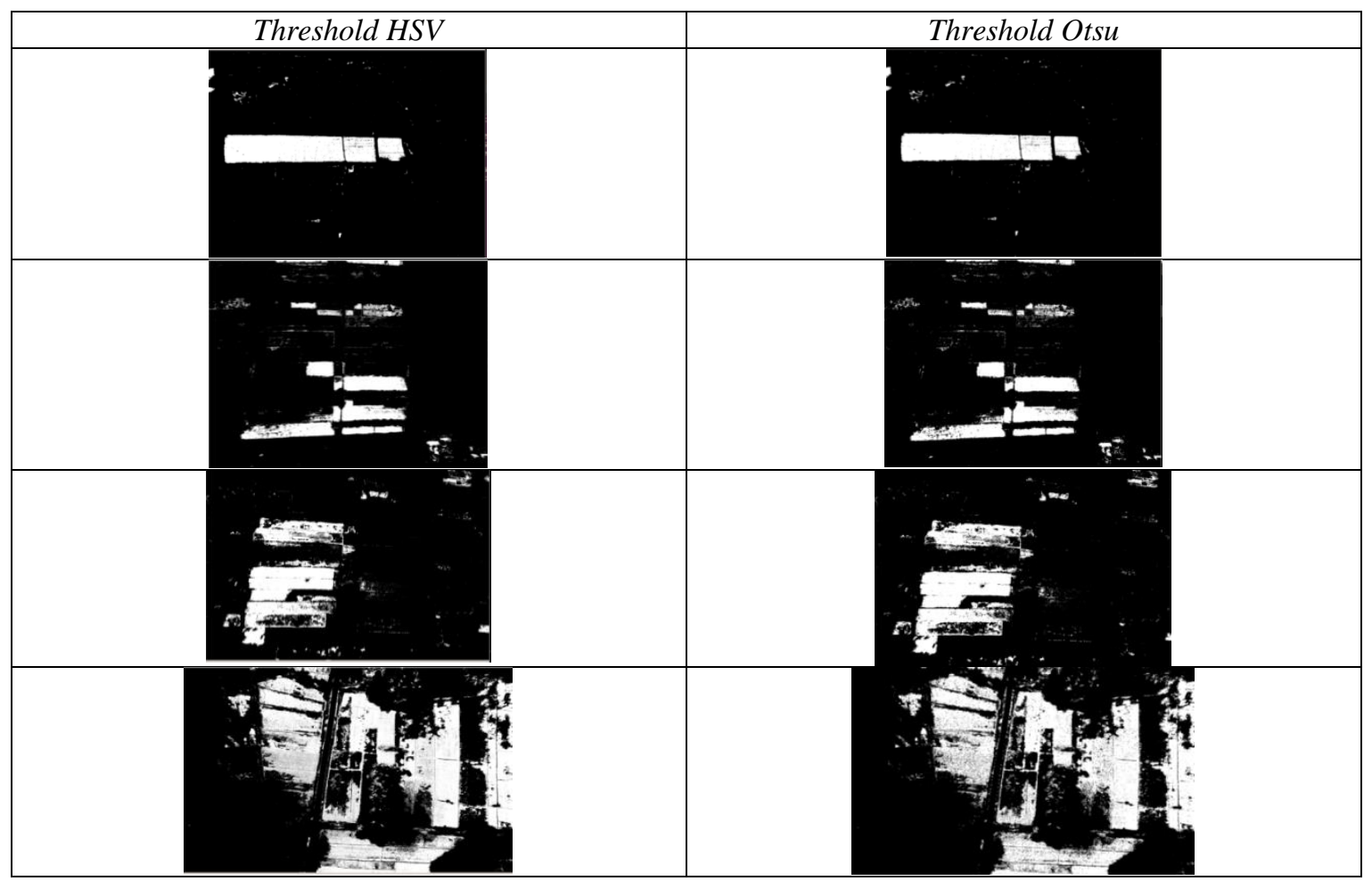

Kemudian pada pendeteksian warna kuning padi menggunakan fungsi inRange dari pustaka openCV yang menggunakan nilai minimum dan maksimum dari warna HSV kemudian 
citra akan berubah menjadi warna hitam dan putih. Warna citra yang masuk pada range yang ditentukan akan berwarna putih dan warna citra yang tidak masuk pada range tersebut akan berwarna hitam. Sehingga pada proses ini dilakukan dua kali thresholding yaitu dengan thresholding pada pendeteksian warna dan kemudian thresholding dengan metode Otsu. Dari hasil perbandingan thresholding di atas tidak dapat dilihat dengan jelas dikarenakan sebelum threshold Otsu dilakukan terlebih dahulu proses thresholding HSV, akan tetapi dalam hasil perhitungan berbeda selisih beberapa angka. Thresholding HSV dilakukan untuk proses pendeteksian warna kuning karena dalam pendeteksian warna ini dari hasil penelitian yang pernah dilakukan oleh peneliti yang lain lebih efektif pendeteksian warna dengan pengolahan warna HSV.

\section{2 pengujian akurasi perhitungan prediksi luas dan hasil panen padi}

Pengujian akurasi perhitungan prediksi luas hasil panen padi dilakukan dengan membandingkan perhitungan langsung luas sawah yang sebenarnya kemudian dilakukan perhitungan dengan sistem. Perhitungan luas sebenarnya dilakukan dengan cara mengukur tepi sawah menggunakan meteran dan kemudian menghitung seluruh sawah yang mempunyai padi yang bewarna kuning atau siap panen. Kemudian perhitungan dengan sistem yang dibuat adalah dengan memasukkan nama file data citra sawah pada terminal kemudian hasil prosesnya akan muncul setelah sistem dijalankan. Hasil perhitungan adalah hasil dari proses perhitungan jumlah piksel yang bewarna putih kemudian dikalikan dengan skala gambar. Skala didapatkan dari hasil perhitungan kalibrasi luas yaitu dengan menghitung hasil sebenarnya dibagi dengan jumlah piksel. Perhitungan kalibrasi ini menggunakan banner yang bewarna putih karena mudah untuk dideteksi. Banner yang digunakan berukuran 8,2 m x 4,26 m. Kemudian nilai kalibrasi dimasukkan dalam program perhitungan. Ketinggian dalam pengambilan foto udara adalah 100 m. Hasil dari proses kalibrasi ini ditunjukan pada Gambar 2.

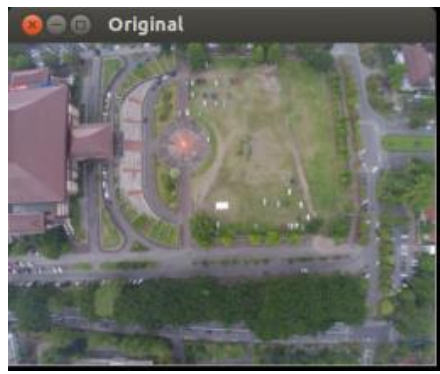

(a)

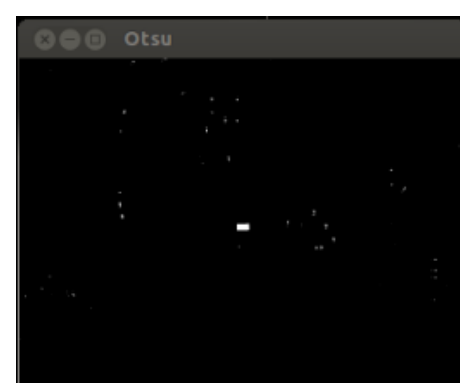

(b)

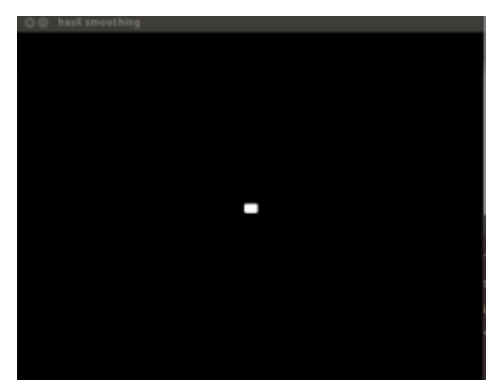

(c)

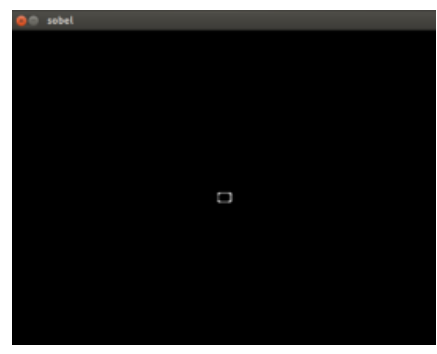

(d)

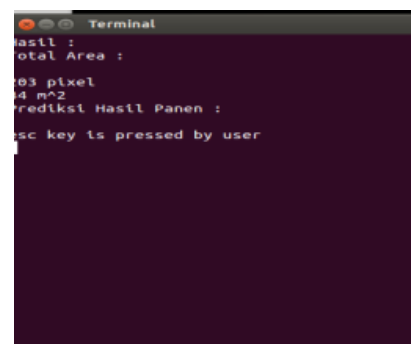

(e)

Gambar 2 Proses kalibrasi luas (a) Foto asli (b) threshold Otsu (c) hasil filtering (d) hasil deteksi tepi (e) hasil perhitungan 
Kemudian data yang digunakan dalam pengujian ini terdapat tiga data yang berhasil dideteksi warna padinya. Data sawah dengan padi yang menguning dari daerah Godean, Sleman. Hasil perhitungan dapat dilihat pada Tabel 3.

Tabel 3 Pengujian perhitungan prediksi luas sawah dan hasil panen

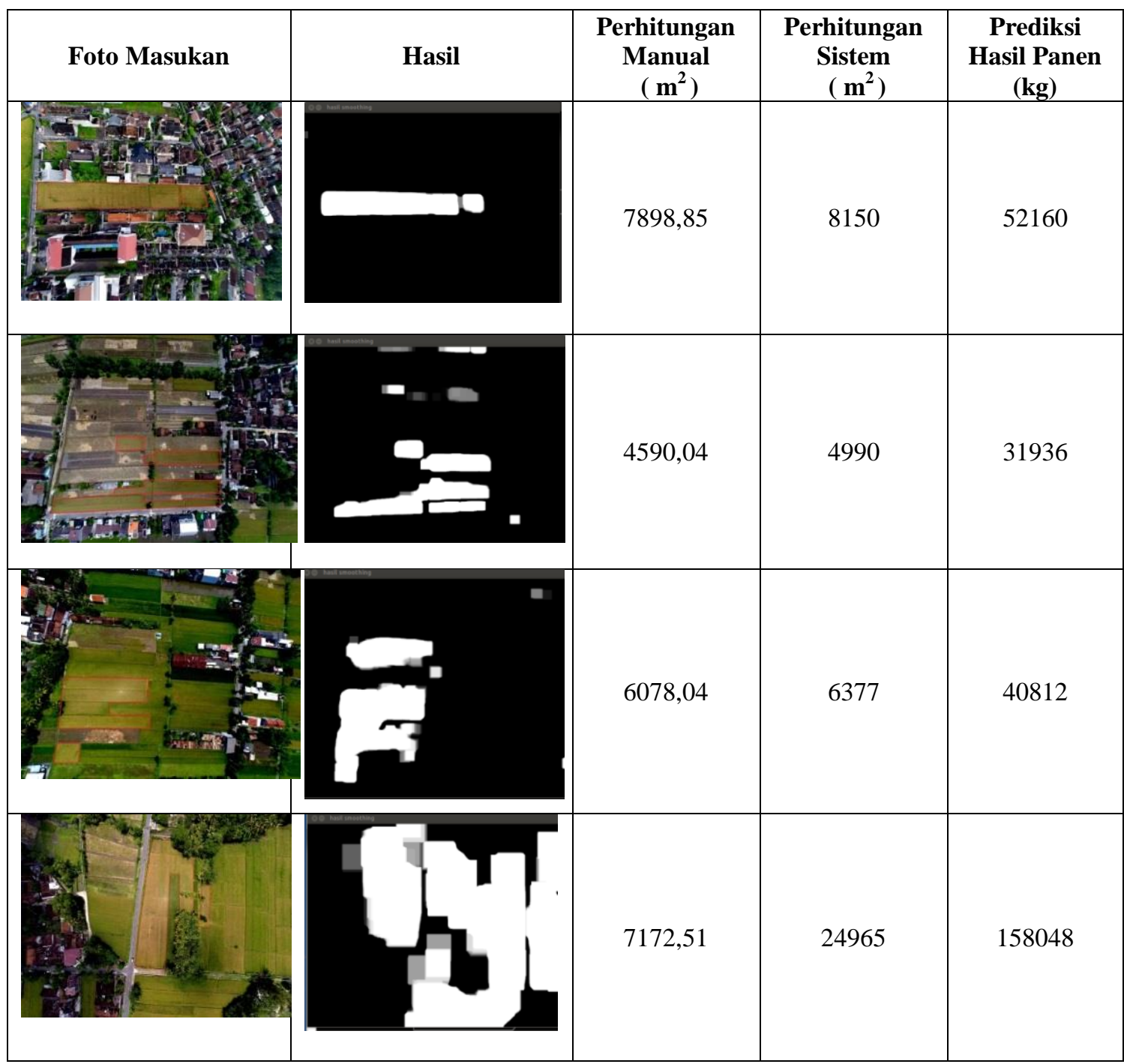

Perhitungan hasil panen didapatkan dari data rata-rata hasil panen pada bulan Januari sampai dengan April dari Badan Pusat Statistik Kota Yogyakarta. Citra sawah yang seharusnya dihitung ditandai dengan garis yang bewarna merah. Perhitungan hasil panen merupakan perkalian antara luas dari perhitungan sistem dengan rata-rata hasil panen pada daerah Sleman pada bulan Januari sampai dengan bulan April. Kemudian dari data diatas, dilanjutkan menghitung error dari hasil perhitungan pada sistem. Tabel 4 merupakan hasil perhitungan error. 
Tabel 4 Hasil perhitungan error

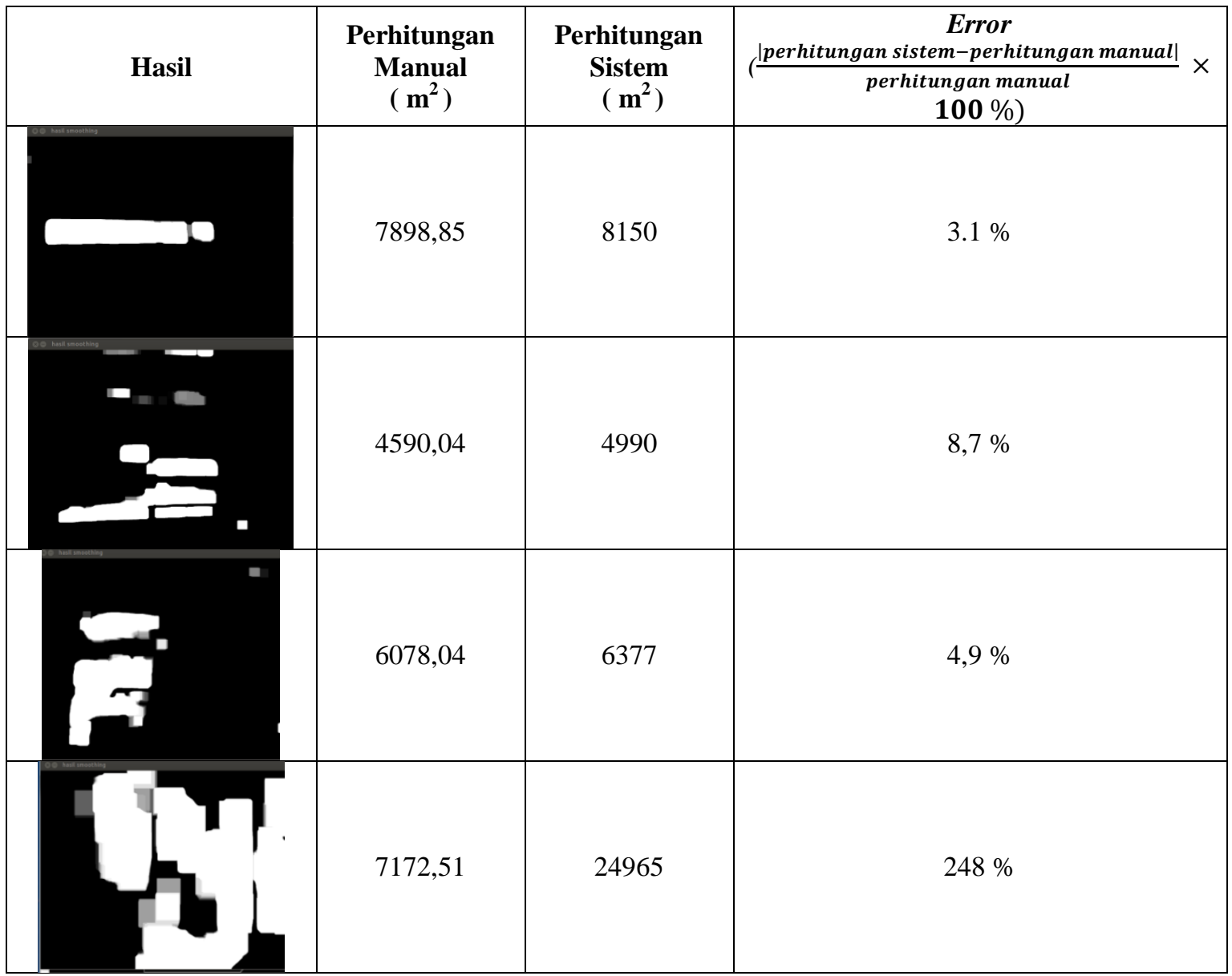

Dari hasil perhitungan citra sawah dengan padi yang menguning dengan cara manual dan perhitungan dari sistem didapatkan tingkat error 3,1\%, 8,7 \%, 4,9\%, dan 248\%. Data terakhir mempunyai tingkat error yang tinggi disebabkan karena pada citra sawah terdapat cahaya yang berlebih sehingga saat pendeteksian warna yang seharusnya hanya pada padi yang menguning saja tetapi pada padi yang bewarna hijau terdeteksi menjadi warna kuning.

Kemudian pada perhitungan masih terdapat error dikarenakan terdapat sawah yang tertutupi oleh pohon dan terdapat noise yang dikarenakan pada sawah dengan padi yang menguning yang tercampur dengan warna padi yang hijau dan terdeteksi oleh sistem.

\section{KESIMPULAN}

Dari hasil pengamatan, pengujian dan analisis pada hasil yang diperoleh, kesimpulan yang dapat diambil adalah sebagai berikut :

1. Rentang warna HSV yang digunakan untuk pendeteksian warna kuning padi adalah 16,6 untuk nilai $\mathrm{H}$ minimal , 106,4 untuk nilai S minimal, dan 70 untuk nilai V minimal. Kemudian untuk rentang nilai yang maksimal adalah 29,6 untuk $\mathrm{H}$ maksimal, 227,8 untuk nilai S maksimal, dan 183 untuk nilai V maksimal, sehingga hasil dari variasi warna padi yang dapat terdeteksi adalah warna padi yang siap panen yaitu dengan warna kuning kecoklatan. 
2. Pengumpulan data yang dilakukan adalah mengambil gambar ketinggian yang dibuat sama yaitu 100 meter, dari permukaan tanah, yang kemudian dikalibrasi dengan ketinggian yang sama.

3. Pada pengujian akurasi perhitungan dari empat data yang diambil masih terdapat error dalam perhitungan yaitu $3,1 \%, 8,7 \%, 4,9 \%$, dan yang terakhir dengan error yang tinggi yaitu $248 \%$.

4. Pada perhitungan sistem masih terdapat error dikarenakan pada pengambilan data udara terdapat perbeda cahaya. Pada data yang keempat tingkat error yang tinggi dikarenakan terdapat pencahayaan yang berlebih serta terdapat area yang tertutupi oleh pohon.

\section{SARAN}

Pengembangan lebih lanjut terkait dengan sistem ini, dapat disarankan untuk melakukan hal sebagai berikut:

1. Sistem prediksi luas dan hasil panen ini dapat dikembangkan pada sistem yang realtime, sehingga saat pengambilan foto udara dapat diketahui luas wilayah yang diambil.

2. Hendakya dapat dikembangkan dengan metode yang lain sehingga pengukuran prediksi luas dan hasil panen dapat menjadi lebih akurat dengan error yang kecil.

3. Sistem perngukuran luas tidak hanya diterapkan pada sawah saja tetapi dapat untuk menghitung luas wilayah yang lain.

\section{UCAPAN TERIMA KASIH}

Penulis mengucapkan terima kasih kepada PPKI UGM yang telah memberi dukungan finansial terhadap penelitian ini.

\section{DAFTAR PUSTAKA}

[1] Bulow, H., dan Birk, A., 2009, Fast and Robust Photommaping with an Unmanned Aerial Vehicle (UAV), Engineering and Science, Jacob Univeristy, Jerman.

[2] Pratiwi, K., dan Murti, S., H., 2012, Aplikasi Pengolahan Digital Citra Penginderaan Jauh dan Sistem Informasi Geografis untuk Pemetaan Lahan Kritis Kasus di Kabupaten Banjarnegara Provinsi Jawa Tengah, Jurnal, Universitas Gadjah Mada, Yogyakarta.

[3] Gusa, R., F., 2013, Pengolahan Citra Digital untuk Menghitung Luas Daerah Penambangan Timah, Jurnal Program Studi Teknik Elektro, Fakultas Teknik, Universitas Bangka Belitung, Bangka Belitung.

[4] Bosak, K., 2011, Secret of UAV Photomapping, Pteryx, Poland.

[5] Shofiyanti, R., 2011, Teknologi Pesawat Tanpa Awak untuk Pemetaan dan Pemantauan Tanaman dan Lahan Pertanian, Jurnal, Balai Besar Penelitian dan Pengembangan Lahan.

[6] Setiyawan, Y., 2013, Purwarupa Sistem Foto Panorama Pada Pesawat Udara Tanpa Awak, Skripsi, Jurusan Ilmu Komputer dan Elektronika, Fakultas Matematika dan Ilmu Pengetahuan Alam, Universitas Gadjah Mada, Yogyakarta.

[7] Chen, W., Yun Q. S., dan Guorong, X., 2006, Identifying Computer Graphics Using HSV Color Model and Statistical Moments of Characteristic Functions, New Jersey Institute of Technology, Newark, NJ, USA.

[8] Hendry, J., 2004, Optimum Global Thresholding using Otsu's Method, EE and IT of UGM, Indonesia.

[9] Crisnanto, H., 2011, Pengendalian Kualitas Cairan dalam Botol Berbasis Pengolahan Citra, Skripsi, Jurusan Teknik Industri, fakultas Teknik, Universitas Sebelas Maret, Surakarta. 
[10] Yuwono, B., 2010, Image Smoothing Menggunakan Mean Filtering, Median Filtering, Modus Filtering, dan Gaussian Filtering, Jurnal, Jurusan Teknik Informatika, UPN "Veteran", Yogyakarta. 